\title{
Pomen obvladovanja stroškov v javnem sektorju
}

UDK: 336.12

\author{
Metka Tekavčič \\ Univerza v Ljubljani, Ekonomska fakulteta \\ metka.tekavcic@ef.uni-lj.si \\ Darja Peljhan \\ Univerza v Ljubljani, Ekonomska fakulteta \\ darja.peljhan@ef.uni-lj.si
}

\section{IZVLEČEK}

Vprašanja obvladovanja stroškov in nadziranja poslovanja so vse aktualnejša tudi v slovenskih organizacijah javnega sektorja. Organizacije, ki so najbolj napredovale na tem področju, uvajajo v svoje poslovanje menedžerska orodja, ki prispevajo $k$ obvladovanju stroškov in ki so se najprej uveljavila v proizvodnem sektorju.

Prispevek se ukvarja $z$ vprašanji obvladovanja stroškov $v$ javnem sektorju. Namen prispevka je predstaviti obvladovanje stroškov in njegov pomen za uspešno delovanje vseh podjetij in drugih organizacij, s posebnim poudarkom na organizacijah javnega sektorja, $v$ katerih se vse bolj uveljavljajo načela in pristopi, ki so sicer značilni za podjetja v zasebnem sektorju. Poleg tega v prispevku predstavljamo uporabo sodobnih menedžerskih orodij, ki prispevajo $k$ obvladovanju stroškov $v$ slovenskih podjetjih, ter na podlagi rezultatov empirične raziskave analiziramo vpliv njihove uporabe na uspešnost podjetij.

Ključne besede: obvladovanje stroškov, javni sektor, menedžerska orodja, Slovenija.

\section{Uvod}

Podjetja in druge organizacije javnega sektorja so zaradi poslanstva, ki ga opravljajo, pomemben in vpliven del družbenega dogajanja. Zanje je dolgo veljalo, da smejo in morajo poslovati predvsem po načelu maksimiranja koristi za stranke oz. uporabnike storitev, ki jih te organizacije opravljajo. Zaostrene razmere poslovanja in spremembe $\vee$ okolju $\vee$ zadnjih letih tudi od organizacij javnega sektorja zahtevajo, da se obnašajo ekonomsko učinkovito ter iščejo ravnotežje med razpoložljivimi sredstvi in potrebami po zdravstvenih storitvah. Organizacije, ki delujejo $\checkmark$ tistem delu javnega sektorja, kjer je njihova dejavnost $v$ veliki meri prepuščena tržnim načelom (predvsem je to pogosto $v$ ZDA), se hitro prilagajajo in $v$ svoje poslovanje vse bolj uvajajo prijeme, ki so se sicer uveljavili v zasebnem sektorju, predvsem $\vee$ proizvodnih organizacijah. Okoliščine zahtevajo, da jim sledijo tudi 
Tekavčič, Peljhan

Pomen obvladovanja stroškov v javnem sektorju

organizacije javnega sektorja $v$ razvitem delu Evrope, medtem ko se $\vee$ Sloveniji ta proces odvija zelo počasi. Razlog je predvsem $v$ pomanjkanju raziskovalnega dela $\checkmark$ ekonomiki javnega sektorja in izobraževalnih programov s tega področja, zaradi česar primanjkuje ustrezno usposobljenih menedžerjev.

Dejstvo je, da so vprašanja obvladovanja stroškov in nadziranja poslovanja vse aktualnejša tudi $v$ slovenskih organizacijah javnega sektorja. Organizacije, ki so najbolj napredovale na tem področju, uvajajo v svoje poslovanje menedžerska orodja, ki so se uveljavila $v$ proizvodnem sektorju. Gre za orodja, povezana z obvladovanjem stroškov in temelječa na obvladovanju aktivnosti, ki so sestavni del procesov $\vee$ organizaciji. Zato je namen prispevka predstaviti obvladovanje stroškov in njegov pomen za uspešno delovanje vseh podjetij in drugih organizacij, s posebnim poudarkom na organizacijah javnega sektorja, kjer se vse bolj uveljavljajo načela in pristopi, ki so sicer značilni za podjetja v zasebnem sektorju.

Prispevek je sestavljen iz treh delov. Najprej obravnavamo obvladovanje stroškov, in sicer kot koncept, ki velja za javni in zasebni sektor ter za vse dejavnosti, proizvodne in neproizvodne. $V$ drugem poglavju poudarimo pomen obvladovanja stroškov $z$ vidika javnega sektorja. $\vee$ tretjem poglavju predstavimo rezultate empirične raziskave "Obvladovanje stroškov v slovenskih podjetjih ", po našem mnenju zelo uporabnih tudi za organizacije javnega sektorja, ki vse pogosteje tudi same vpeljujejo novejša menedžerska orodja v svoje poslovanje.

\section{Obvladovanje stroškov'}

Moderno obvladovanje stroškov, ki se še razvija, temelji na stroškovnem in poslovodnem računovodstvu. Obvladovanje stroškov zahteva znanje tako stroškovnega kot poslovodnega računovodstva, čeprav se njegov namen in metode, ki jih uporablja, bistveno razlikujejo od tistih, ki jih uporabljata stroškovno in poslovodno računovodstvo. Glavni namen stroškovnega računovodstva je vrednotenje zalog in kalkuliranje stroškov prodanih poslovnih učinkov za namene finančnih izkazov podjetja. Drugače povedano, stroškovno računovodstvo je osredotočeno na zunanje finančno poročanje. Obvladovanje stroškov pa se osredotoča predvsem na proces notranjega odločanja $v$ podjetju.

Namen poslovodnega računovodstva je, da ponuja informacije za podporo odločanju o poslovanju podjetja. Metode, ki jih pri tem uporablja, so predmet številnih razprav že od sredine osemdesetih let. Kritiki poudarjajo predvsem, da tradicionalni pristopi poslovodnega računovodstva ne zagotavljajo ustreznih in pravočasnih informacij za odločanje menedžerjev. Rezultat tradicionalnih sistemov spremljanja stroškov naj bi prepogosto bile netočne in zavajajoče informacije o stroških poslovnih učinkov in kupcev. Ti sistemi se namreč preveč osredotočajo

1 Ta del prispevka velja za javni in zasebni sektor ter za vse dejavnosti, proizvodne in neproizvodne. 
na pretekle informacije. Poleg tega jemljejo podjetje kot enoto analize in ne upoštevajo celotne verige vrednosti (angl. supply chain), v kateri posamezno podjetje pomeni le enega od členov. Tradicionalni sistemi spremljanja stroškov tudi prepogosto prispevajo $k$ nefunkcionalnemu vedenju, ki se med drugim kaže $v$ proizvodnji presežnih zalog z namenom porazdelitve splošnih stroškov na čim večje število poslovnih učinkov ter $v$ nabavi surovin, ki ne ustrezajo ustreznim standardom, in sicer zaradi doseganja postavljenih ciljev o višini prodajnih cen (Handbook of Cost Management, 2001).

Obvladovanje stroškov se večinoma osredotoča na informacije, ki zadevajo celoten proces razvoja in izdelave poslovnega učinka in stroške po posameznih kupcih. Obvladovanje stroškov je podjetju $v$ pomoč pri izboljševanju poslovnih učinkov in procesov, saj opozarja na aktivnosti, ki ne dodajajo vrednosti, in ponuja ustrezna orodja za zmanjšanje oz. odpravo opravljanja teh aktivnosti. Moderno obvladovanje stroškov zahteva poznavanje stroškovnega in poslovodnega računovodstva, poleg tega pa zahteva tudi zelo dobro poznavanje vseh poslovnih procesov in celotne verige vrednosti. Menedžerji, ki se trudijo obvladovati stroške, namreč ne morejo meriti in obvladovati tistega, česar ne razumejo.

Veliko je različnih mnenj o tem, katera osnovna orodja, tehnike in metode so neposredno ali posredno povezani z obvladovanjem stroškov. $V$ prispevku jih bomo poimenovali sodobna menedžerska orodja, med katera uvrščamo orodja, ki so namenjena naprednim strateško usmerjenim podjetjem. $V$ literaturi' so najpogosteje omenjena naslednja orodja: koncept stroškov po aktivnostih poslovnega procesa - SAPP (angl. Activity-Based Costing - ABC), predračunavanje na podlagi aktivnosti (angl. Activity-Based Budgeting - $A B B$ ), poslovodenje na temelju analize aktivnosti (angl. Activity-Based Management - ABM), koncept stroškov življenjskega cikla poslovnega učinka ${ }^{\mathbf{3}}$ (angl. Life-Cycle Costing), koncept ciljnih stroškov (angl. Target Costing), teorija omejitev (angl. Theory of Constraints - TOC), benchmarking, ${ }^{4}$ ravno ob pravem času (angl. Just-in-time - JIT), celovito obvladovanje kakovosti (angl. Total Quality Management - TQM), koncept stalnih izboljšav poslovanja (angl. Continuous Improvement), prenova poslovnih procesov (angl. Business

2 Izbrali smo tista menedžerska orodja, ki so najpogosteje omenjena $v$ literaturi o obvladovanju stroškov, kot so npr. Handbook of Cost Management, Guide to Cost Management, Emerging Practices in Cost Management, and Emerging Practices in Cost Management: Strategic Cost Management.

3 Poslovni učinki so "skupno ime za proizvode in opravljene storitve kot posledke poslovnega procesa« (Turk, 2000). S poslovnimi učinki torej mislimo na proizvode in storitve, kar velja za uporabo pojma poslovni učinek $v$ okviru celotnega prispevka.

$4 \mathrm{~V}$ okviru prispevku uporabljamo izraz benchmarking, ki je $\mathrm{v}$ slovenskem prostoru dobro poznan. Pomeni postopek primerjanja določenega procesa z enakimi procesi v svetovno uspešnih podjetjih, pri čemer se raven učinkovitosti opravljanja posameznih aktivnosti $v$ tem procesu $v$ vodilnih svetovnih podjetjih postavi kot cilj, ki ga podjetje uresničuje, ali kot norma, s katero primerja lastno raven opravljanja teh aktivnosti (Tekavčič, 1996). V slovenski strokovni literaturi je izraz benchmarking že dobro uveljavljen, posamezni avtorji pa ga prevajajo kot primerjalno presojanje, primerjalno ocenjevanje, posnemovalno primerjanje, poslovodenje na temelju usmernikov, količenje in podobno. 
Tekavčič, Peljhan

\section{Pomen obvladovanja stroškov v javnem sektorju}

Process Reengineering - BPR) in uravnoteženi izkaz poslovanja (angl. Balanced Scorecard - BSC). Pri vseh sodobnih menedžerskih orodjih gre za poskuse iskanja novih rešitev za povečanje uspešnosti poslovanja v sodobnem poslovnem okolju, ki od podjetij zahteva doseganje poslovne odličnosti.

Sodobna menedžerska orodja so se $v$ tujini (s tem mislimo predvsem na ZDA, Japonsko in države EU) začela intenzivno uvajati že od sredine sedemdesetih oz. od začetka osemdesetih let dvajsetega stoletja, predvsem s pomočjo raznih svetovalnih podjetij. Naj navedemo nekaj primerov. Po podatkih raziskave, ki jo je izvedlo svetovalno podjetje Ernst \& Young za potrebe American Quality Foundation, kar 60 \% ameriških podjetij iz štirih pomembnih dejavnosti (izdelava računalnikov, proizvodnja avtomobilov, banke in bolnišnice) redno uporablja 'benchmarking' (Beretta, Dossi, Grove, 2000). Po podatkih raziskave iz leta 1998 za potrebe Cost Management Group z inštituta Institute of Management Accountants je $35 \%$ ameriških podjetij že imelo vzpostavljen uravnoteženi izkaz poslovanja ali pa ga je vpeljevalo.

$\checkmark$ okviru obravnave sodobnih menedžerskih orodij je treba poudariti dvoje. Prvič, vrstni red obravnavanja posameznih orodij ni povezan z vplivom, ki ga ima uporaba orodij na uspešnost poslovanja podjetja. Sodobno usmerjena podjetja morajo namreč poznati vsa orodja ter jih kritično uporabiti glede na naravo svojega poslovanja, ne pa zaradi orodja samega. Posamezna orodja so med seboj zelo povezana in za podjetje koristna šele takrat, ko zna izkoristiti možnosti, ki mu jih ta orodja ponujajo. Drugič, nekatera orodja so neposredno povezana z obvladovanjem stroškov, druga pa so celostna menedžerska orodja, ki se le $v$ posameznih elementih nanašajo na obvladovanje stroškov. $V$ nadaljevanju zaradi poenostavitve govorimo o sodobnih menedžerskih orodjih. $\vee$ prispevku ne nameravamo podrobneje razpravljati o posameznem orodju. O njih je bilo že veliko napisano, zato lahko bralec, ki bi se rad podrobneje seznanil s posameznim menedžerskim orodjem, prouči navajane reference $v$ Tekavčič, Šink (2002a).

Pravilna določenost in obravnava sodobnih menedžerskih orodij omogočata lažje odločanje o poslovanju podjetjem, ki se spoprijemajo s spremembami sodobnega poslovnega okolja. Ob tem je treba omeniti analizo aktivnosti, ki je nedvomno eden pomembnejših temeljev orodij modernega poslovodenja. Temelji na uporabi informacij, pridobljenih s sistemi stroškov, ki temeljijo na sodobnih menedžerskih orodjih. Praktično vsa sodobna menedžerska orodja, ki se razvijajo zaradi povečevanja učinkovitosti in uspešnosti poslovanja, zahtevajo poznavanje značilnosti posameznih aktivnosti poslovnega procesa. Pomembno je, da se podjetja osredotočijo na aktivnosti, ki prispevajo k vrednosti z vidika zahtev kupcev. Skrčiti ali celo odpraviti morajo vse aktivnosti, ki $k$ tej vrednosti ne prispevajo. $\vee$ podjetju si morajo prizadevati, da povečajo število aktivnosti, ki prispevajo k vrednosti z vidika kupcev, ter da povečajo učinkovitost opravljanja zaželenih in potrebnih aktivnosti. 
Oboje vodi h končnemu cilju, ki je povečanje dobička z doseganjem višjih prodajnih cen in znižanjem stroškov poslovanja. ${ }^{\mathbf{5}}$

\section{Pomen obvladovanja stroškov v javnem sektorju}

Avtorji, ki proučujejo obvladovanje stroškov v javnem sektorju (glej npr. Ball, 2001; Han, 1991; Kline, 2003), opozarjajo, da se organizacije javnega sektorja že več kot dve desetletji spopadajo z okoljem, ki je sicer značilno za podjetja, ki v konkurenčnih razmerah poslujejo po načelih tržnega gospodarstva. Spopadati se morajo z naraščajočimi pritiski po zmanjševanju stroškov ob hkratnih zahtevah po boljši kakovosti opravljenih storitev. Organizacije javnega sektorja se vse bolj spoprijemajo s podobnimi težavami kot podjetja, ki želijo preživeti $\vee$ razmerah zaostrene konkurence na zahtevnih svetovnih trgih. Tako kot morajo podjetja slediti nenehno spreminjajočim se zahtevam kupcev, ki ob poplavi sorodnih poslovnih učinkov upravičeno pričakujejo poceni, a visokokakovostne poslovne učinke, morajo tudi organizacije javnega sektorja vse bolj upoštevati stranke oz. uporabnike svojih storitev.

$\mathrm{V}$ primeru javnega sektorja ima usmerjenost $\mathrm{k}$ uporabniku (stranki) meje, ki jih postavlja javni interes. Zadovoljstva uporabnika ne smemo postavljati pred interese drugih ali pred javni interes, ki ga določa zakon (Virant, 2003, str. 68). Navadno je ovira za doseganje večjega zadovoljstva uporabnikov dejstvo, da imajo organizacije javnega sektorja večinoma monopolni položaj. Zato se za povečevanje kakovosti storitev in zadovoljstva uporabnikov uporabljajo različni netržni mehanizmi, npr. ko vlada z obvezujočimi standardi (predpisi) usmerja upravne organe $\mathrm{k}$ uporabniku (gre za t. i. prijazno upravo in razne antibirokratske programe).

Lahko ugotovimo, da je izzivov za organizacije $v$ javnem sektorju vedno več. $\checkmark$ takšnih razmerah morajo organizacije javnega sektorja, tako kot podjetja iz zasebnega sektorja, pristati na logiko poslovne odličnosti. S poslovno odličnostjo običajno označujemo "stroškovno učinkovito povezanost aktivnosti znotraj vseh organizacijskih enot, katere namen je nenehno izboljševanje poslovnih učinkov, ki zadovoljujejo želje kupcev" ${ }^{\mathbf{6}}$ (Brimson, 1991, str. 5). Tudi od slovenskih organizacij javnega sektorja se vse bolj zahteva izjemno prožno poslovanje, ki omogoča hitro odzivanje na spremembe $v$ okolju. Zato se morajo zavedati nujnosti uvajanja sprememb, ki omogočajo izboljšanje njihovega delovanja ter doseganje boljših rezultatov ter s tem povečanje uspešnosti poslovanja. $V$ takšnih razmerah potrebujejo informacije, ki ne bodo kazale zgolj finančnega stanja in uspeha organizacij, pač pa tudi druge zmožnosti, predvsem človeške, tehnološke in razvojne. Država

5 Več o analizi aktivnosti kot izhodišču za obvladovanje stroškov in povečevanju uspešnosti poslovanja glej npr. v Tekavčič, 2001, str. 303-308.

$6 \mathrm{~V}$ primeru javnega sektorja gre za stranke oz. uporabnike storitev, ki jih opravljajo organizacije javnega sektorja. 
Tekavčič, Peljhan

Pomen obvladovanja stroškov v javnem sektorju

mora z menedžmentom organizacij javnega sektorja svojim državljanom zagotoviti ustrezno kakovost storitev, ki jih opravljajo te organizacije, hkrati pa vzpostaviti mehanizme, ki bodo omogočali nadzor nad poslovanjem organizacij, ki jih financira. To pomeni, da mora od organizacij javnega sektorja zahtevati spoštovanje logike poslovne odličnosti in iskanje načinov za zagotavljanje visoke kakovosti opravljenih storitev ob čim nižjih stroških poslovanja. S tem se od vseh organizacij javnega sektorja zahtevajo učinkovito načrtovanje, organiziranje, vodenje in nadzor procesov, ki potekajo v organizaciji, in hkrati zagotavljanju njihove stroškovna učinkovitost. Organizacije javnega sektorja zato potrebujejo menedžment, ki bo sposoben obvladati aktivnosti v organizaciji in s tem tudi stroške, ki jih te aktivnosti povzročajo.

Omenili smo že, da so sodobna menedžerska orodja $v$ tujini (s tem mislimo predvsem na ZDA, države Evropske unije in Japonsko) že dodobra poznana in uveljavljena. Prav tako so že znane številne pozitivne izkušnje z uvajanjem teh konceptov $v$ podjetja ter uspešnim poslovanjem z njihovo pomočjo. Kako pa je z uporabo teh sodobnih menedžerskih orodij pri nas, v Sloveniji? Kot nam je znano, do zdaj na tem področju še ni bila izvedena poglobljena raziskava, ki bi $v$ celoti odgovorila na to vprašanje, zato smo $v$ okviru raziskovalnega programa Management, organizacija in poslovna informatika na Ekonomski fakulteti $\vee$ Ljubljani izpeljali raziskavo z naslovom "Obvladovanje stroškov v slovenskih podjetjih «.

$\checkmark$ nadaljevanju na podlagi rezultatov opravljene raziskave analiziramo uporabo sodobnih menedžerskih orodij $v$ slovenskih podjetjih ter njihov vpliv na uspešnost poslovanja. Rezultati omenjene analize so po našem mnenju zelo uporabni tudi za organizacije javnega sektorja, ki vse pogosteje tudi same vpeljujejo novejša menedžerska orodja $v$ svoje poslovanje. Sicer se med menedžerskimi orodji, ki se najpogosteje uporabljajo v javnem sektorju, omenjajo predvsem koncept stroškov po aktivnostih poslovnega procesa (Ball, 2001; Kline, 2003; Tekavčič, 2001), benchmarking (Ball, 2001; Kline, 2003; Poulin, 2004) in uravnoteženi izkaz poslovanja (Kaplan, 2000; Hoque idr., 2004). Tudi $v$ tuji strokovni literaturi ni zaslediti poglobljene raziskave o uporabi menedžerskih orodij, ki prispevajo k obvladovanju stroškov v javnem sektorju. Pojavljajo se le posamezne študije primerov organizacij javnega sektorja, ki so uspešno vpeljale katero od menedžerskih orodij v svoje poslovanje; te pa so lahko zelo dobra osnova za nadaljnje proučevanje uporabe teh orodij na večjem vzorcu organizacij javnega sektorja. To je zagotovo izziv za strokovnjake s področja obvladovanja stroškov tako v Sloveniji kot v tujini.

\section{Izsledki empirične raziskave v slovenskih podjetjih}

Okolje, v katerem poslujejo slovenska podjetja, se je $v$ minulem desetletju že spremenilo tako, da se uspešno poslovanje nagradi, neuspešno pa kaznuje. Menedžerji, ki so odgovorni za uspešno poslovanje, in tisti, ki morajo menedžerjem in drugim nosilcem odločanja zagotoviti ustrezne informacije za 
menedžerjem in drugim nosilcem odločanja zagotoviti ustrezne informacije za odločanje, so v tržnem okolju prisiljeni upoštevati nove okoliščine poslovanja, ki od podjetij in njihovih zaposlenih zahtevajo drugačno vedenje kot $v$ preteklosti. To bi se moralo pokazati tudi v uvajanju in uporabi sodobnih menedžerskih orodij, kar smo z anketnimi vprašalniki ugotavljali v okviru raziskave "Obvladovanje stroškov v slovenskih podjetjih «.

\subsection{Opis raziskovalnega pristopa}

Glavni vir podatkov za empirično analizo je raziskava "Obvladovanje stroškov v slovenskih podjetjih«, ki je bila izvedena pozimi 2000/2001. Empirična raziskava temelji na obsežnem vprašalniku z vnaprej ponujenimi odgovori pri večini vprašanj. Z anketiranjem $\vee$ slovenskih podjetjih (anketirani so bili zaposleni, ki sestavljajo višje strukture $v$ podjetju, od (naj)višjih in srednjih menedžerjev do vodij računovodskih služb, služb kontrolinga ipd.) smo dobili 264 uporabnih izpolnjenih anketnih vprašalnikov, na katerih temeljijo empirične ugotovitve. Kot tehniko anketiranja smo izbrali osebne razgovore, saj menimo, da je s tovrstno tehniko mogoče pridobiti natančnejše in popolnejše odgovore na zastavljena vprašanja kot z drugimi (npr. anketiranje po pošti, telefonsko ali elektronsko anketiranje), še posebno zaradi relativno dolgega vprašalnika. Pri osebnem anketiranju lahko anketar takoj pojasni morebitne nejasnosti v zvezi z navodili ali vprašanji. Druge prednosti osebnega anketiranja so relativno hitro zbrani podatki, izvrstno sodelovanje anketirancev, nizko število neodgovorjenih vprašanj in najmanjša verjetnost nerazumevanja pri anketiranih (Zikmund, 2000).

Osebno anketiranje smo opravili s pomočjo 100 ustrezno usposobljenih anketarjev. ${ }^{7}$ Vsak anketar je anketiral dve do tri podjetja. Slovenija je relativno majhna država (20.296 km2, dva milijona prebivalcev), zato smo lahko vključili skoraj vsa geografska območja z relativno nizkimi stroški, kar ni običajna praksa pri osebnem anketiranju (Zikmund, 2000). Gre za razmeroma velik vzorec 264 podjetij, ${ }^{\mathbf{8}}$ ki po velikosti podjetij, geografsko in panožno dobro predstavlja populacijo. Pri izboru

7 Anketarji so bili ustrezno usposobljeni, saj je bilo anketiranje del raziskovalnega dela pri predmetu Ekonomika in analiza poslovanja podjetja $v$ okviru podiplomskega študija na Ekonomski fakulteti $v$ Ljubljani. Predmet je med drugim vključeval predavanja na temo novejših pristopov v zvezi z obvladovanjem stroškov, tako da so bili študenti anketarji za izpolnjevanje vprašalnika primerno strokovno usposobljeni. Poleg tega smo jim podrobno predstavili anketna vprašanja z utemeljitvijo, na kaj se nanaša posamezno vprašanje oz. kaj zahteva od anketiranega. Tako so študenti anketirancem lahko sproti (ob anketiranju) pojasnili morebitne nejasnosti glede posameznih vprašanj. S tem smo se izognili temu, da anketiranci ne bi pravilno razumeli vprašanj in bi bili zato njihovi odgovori neuporabni.

8 Vzorec se šteje za razmeroma majhnega, če ima manj kot 100 enot (Košmelj, Rovan, 2000), zato lahko trdimo, da je naš vzorec, ki to mejo krepko presega, velik. 
Tekavčič, Peljhan

\section{Pomen obvladovanja stroškov v javnem sektorju}

podjetij $\vee$ vzorec nismo imeli namena zaobiti nobenega podjetja. Naša tehnika vzorčenja ima značilnosti priložnostnega vzorčenja. ${ }^{9}$

Podatki so bili zbrani z vprašalnikom, ki je razdeljen na pet delov oz. vsebinskih sklopov vprašanj: glavni podatki o podjetju ( $v$ tem delu smo zbrali podatke o dejavnosti podjetja, letu ustanovitve podjetja, pravnoorganizacijski obliki in lastniški strukturi, sektorju, kamor sodi podjetje, o trgih, na katerih pretežno deluje, ravni konkurence na glavnem prodajnem trgu in podobno); sistem spremljanja in obvladovanja stroškov ter merjenja in presojanja uspešnosti poslovanja; finančni in nefinančni vidik informacij o poslovanju za potrebe odločanja v podjetju; sodobna menedžerska orodja ter komentarji, opombe, predlogi (ta del je bil namenjen komentarjem posameznih odgovorov, morebitnim pripombam in predlogom anketirancev).

Za potrebe naše empirične analize, ki se nanaša na uporabo sodobnih menedžerskih orodij, bomo upoštevali predvsem rezultate (odgovore podjetij) četrtega dela vprašalnika, ki nam bodo pomagali ugotoviti, kakšno je dejansko stanje na področju uporabe sodobnih menedžerskih orodij v slovenskih podjetjih. $\checkmark$ tem delu smo najprej ugotavljali, ali podjetja poznajo posamezna menedžerska orodja, ali menijo, da bi jih bilo smiselno uvesti, ali mogoče že načrtujejo uvajanje katerega izmed njih, ali katerega izmed orodij že uvajajo ali celo uporabljajo.

$\checkmark$ okviru raziskave smo anketirali 86 majhnih, ${ }^{\mathbf{1 0}} 62$ srednjih in 116 velikih podjetij. Po velikosti je v vzorcu torej $33 \%$ majhnih podjetij, $24 \%$ srednjih podjetij ter $44 \%$ velikih podjetij. $\vee$ vzorcu 264 slovenskih podjetij je 35,2 \% proizvodnih podjetij, $15,2 \%$ trgovskih, $36 \%$ je storitvenih podjetij, 13,6 \% podjetij pa se je opredelilo za kombinacijo prej navedenih možnosti. 40,2 \% podjetij je bilo ustanovljenih leta 1991 ali pozneje. V vzorcu je skoraj enako število delniških družb $(43,9$ \%) in družb z omejeno odgovornostjo $(44,7 \%)$, druga podjetja pa se uvrščajo med samostojne podjetnike, javna podjetja in druge pravnoorganizacijske oblike podjetij. Največ podjetij je $\vee$ zasebni lasti, in sicer 58,7 \%, v mešani lasti je $36 \%$ podjetij, 5,3 \% podjetij pa je $v$ državni lasti. Od podjetij, ki so odgovarjala na vprašalnik, je 6,1 \% podjetij podružnic kakega drugega podjetja. $\vee$ vzorec zajeta podjetja imajo $\vee 71,6 \%$ primerov kot glavni trg slovenski, $\vee 21,6 \%$ primerov gre za kombinacijo več trgov, $3,8 \%$ podjetij je opredelilo kot glavni nemški trg, 2,7\% podjetij italijanski trg in le $0,4 \%$ podjetij avstrijski trg. Izmed vprašanih podjetij jih je 9,8 \% takih, ki so na dan 31. 12. 1999 izkazovala izgubo.

9 Več o priložnostnem vzorčenju glej npr. v Churchill, 1999, str. 502, in Zikmund, 2000, str. 350. 10 Podjetja smo razvrstili po velikosti glede na merila, ki jih določa 51. člen zakona o gospodarskih družbah, veljaven $v$ času naše raziskave. 
$\checkmark$ okviru empirične analize bomo na podlagi pridobljenih podatkov najprej ugotovili, kakšno je stanje na področju uporabe sodobnih menedžerskih orodij v slovenskih podjetjih.

\subsection{Uporaba sodobnih menedžerskih orodij $v$ slovenskih podjetjih}

$\checkmark$ preglednici 1 predstavljamo rezultate analize uporabe sodobnih menedžerskih orodij $\vee$ slovenskih podjetjih. Lahko ugotovimo, da slovenska podjetja slabo poznajo teorijo omejitev (pozna jo $45 \%$ podjetij), poslovodenje na temelju analize aktivnosti (pozna ga $54 \%$ ) in koncept stroškov življenjskega cikla poslovnega učinka (pozna ga 56 \% podjetij). Najbolje poznana orodja pa so celovito obvladovanje kakovosti (pozna ga $77 \%$ podjetij), koncept stalnih izboljšav poslovanja (pozna ga $73 \%$ podjetij) in ravno ob pravem času (pozna ga $72 \%$ podjetij). ${ }^{11}$ Čeprav so ti trije koncepti najbolj poznani, moramo opozoriti na to, da je še vedno kar nekaj (približno četrtina) slovenskih podjetij, ki jih ne poznajo, čeprav se v tujini intenzivno uvajajo že od začetka osemdesetih let.

Slovenska podjetja največ uvajajo in uporabljajo koncept stalnih izboljšav poslovanja (22\% podjetij), celovito obvladovanje kakovosti (20\% podjetij) in benchmarking (17 \% podjetij). Najmanj pa uvajajo in uporabljajo koncept stroškov življenjskega cikla poslovnega učinka (4\% podjetij), poslovodenje na temelju analize aktivnosti (5\% podjetij) in uravnoteženi izkaz poslovanja (7 \% podjetij), ob upoštevanju dejstva, da teorije omejitev ne uvaja in uporablja nobeno od anketiranih podjetij. ${ }^{\mathbf{1 2}} \mathrm{Ob}$ tem moramo opozoriti na posamezna slovenska podjetja, ki so bila "pionirji« pri vpeljavi sodobnih menedžerskih orodij v svoja poslovanja, kot sta npr. Lek (na področju koncepta SAPP) in Iskra Avtoelektrika (na področju uravnoteženega izkaza poslovanja).

11 Za koncept ravno ob pravem času smo sicer ugotovili, da je relativno dobro poznan, kljub temu pa ga uporablja le 6 \% podjetij, uvaja pa ga 7 \% podjetij. Zagotovo je zaskrbljujoče dejstvo, da kar $41 \%$ podjetij ne uvaja ali uporablja koncepta ravno ob pravem času oz. meni, da to ni smiselno. Po našem mnenju bi bilo smiselno anketo ponoviti v več zaporednih obdobjih (npr. vsako leto ali dve), da bi lahko spremljali, kako se giblje odnos podjetij do tega pristopa, ki je v ameriškem, evropskem, še posebno pa v japonskem prostoru močno prisoten že od sedemdesetih let prejšnjega stoletja. Slovenska podjetja se morajo zavedati dejstva, da bodo, če bodo hotela konkurirati kot dobavitelji v globalnem prostoru, od njih uvedbo tega pristopa terjali njihovi odjemalci. Kot kaže, poslovanje v slovenskem prostoru (po rezultatih raziskave je za 72 \% podjetij prevladujoč trg še vedno slovenski) še ne sili podjetij $\vee$ uvedbo omenjenega pristopa.

12 Ta rezultat je posledica dejstva, da se v slovenski strokovni literaturi ta pristop zanemarja (o konceptu je podrobneje pisala le Tekavčičeva (1999 in 1999a)), prav tako ga v nasprotju z ameriškimi in evropskimi učbeniki praktično ni zaslediti $v$ slovenskih učbenikih $s$ področja poslovodnega in stroškovnega računovodstva. 
Tekavčič, Peljhan

Pomen obvladovanja stroškov v javnem sektorju

\section{Preglednica 1: Poznavanje in uporaba sodobnih menedžerskih orodij v slovenskih podjetjih v \%}

\begin{tabular}{|c|c|c|c|c|c|c|}
\hline Sodobno menedžersko orodje & 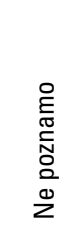 & 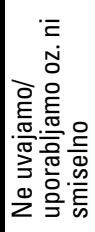 & 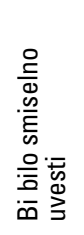 & 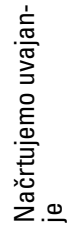 & $\begin{array}{l}\stackrel{0}{\frac{E}{\sigma}} \\
\frac{\pi}{\pi} \\
\stackrel{3}{3}\end{array}$ & 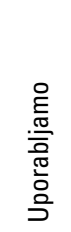 \\
\hline Koncept SAPP & 34,1 & 33,0 & 11,7 & 7,6 & 5,3 & 8,3 \\
\hline Predračunavanje na podlagi analize aktivnosti & 40,2 & 35,6 & 7,6 & 6,4 & 3,0 & 7,2 \\
\hline Poslovodenje na temelju analize aktivnosti & 46,2 & 37,5 & 6,4 & 4,5 & 1,9 & 3,4 \\
\hline $\begin{array}{l}\text { Koncept stroškov življenjskega cikla } \\
\text { poslovnega učinka }\end{array}$ & 44,3 & 41,3 & 8,0 & 2,7 & 0,8 & 3,0 \\
\hline Koncept ciljnih stroškov & 32,2 & 37,5 & 12,1 & 4,9 & 3,0 & 10,2 \\
\hline Teorija omejitev & 55,3 & 40,5 & 2,7 & 1,5 & 0,0 & 0,0 \\
\hline Benchmarking & 34,1 & 32,6 & 13,3 & 2,7 & 4,5 & 12,9 \\
\hline Ravno ob pravem času & 28,0 & 40,9 & 15,5 & 2,7 & 6,8 & 6,1 \\
\hline Celovito obvladovanje kakovosti & 23,1 & 32,6 & 16,3 & 8,0 & 7,6 & 12,5 \\
\hline Koncept stalnih izboljšav poslovanja & 26,9 & 31,1 & 14,0 & 6,1 & 8,0 & 14,0 \\
\hline Prenova poslovnih procesov & 39,0 & 34,1 & 8,0 & 5,7 & 6,1 & 7,2 \\
\hline Uravnoteženi izkaz poslovanja & 38,5 & 37,8 & 11,5 & 5,7 & 3,1 & 3,4 \\
\hline
\end{tabular}

*Opomba: Podjetja, ki so odgovorila, da ni smiselno uvajati oz. uporabljati posameznih orodij, so sicer z njimi seznanjena.

Vir: Rezultati raziskave "Obvladovanje stroškov v slovenskih podjetjih«, 2000/2001.

Slovenska podjetja $v$ primerjavi s tujimi (glej primere $v$ uvodnem delu prispevka) uporabljajo sodobna menedžerska orodja $\vee$ relativno majhnem obsegu. Kljub temu pa lahko omenimo nekatera pozitivna gibanja na tem področju, ki lahko pripomorejo k večji uporabi omenjenih orodij:

- $\quad V$ prihodnjih nekaj letih lahko pričakujemo še večje stopnjo poznavanja in uporabe pristopov celovitega obvladovanja kakovosti in stalnih izboljšav poslovanja, tudi kot posledico uvajanja projekta "Spodbujanje uvajanja celovitega sistema stalnih izboljšav v podjetjih po metodi 20 ključev«, ki ga izvaja ministrstvo za gospodarstvo. ${ }^{13}$

13 Celoten projekt je zastavljen v štirih fazah, v vsaki naj bi se $v$ projekt vključilo po petnajst podjetij. Prva skupina podjetij je začela projekt spomladi leta 2000, druga pa jeseni leta 2000; $\vee$ projekt je trenutno vključenih 29 podjetij vseh velikosti, ki se ukvarjajo z različnimi dejavnostmi. Več o metodi 20 ključev in omenjenem projektu glej v Kruhar, 2001, str. 35 
- $\vee$ prihodnosti lahko pričakujemo tudi večje poznavanje in uporabo benchmarkinga, predvsem kot posledico uvajanja projekta "Zunanji benchmarking " ministrstva za gospodarstvo, ${ }^{\mathbf{1 4}}$ saj sta med glavnimi cilji projekta tudi seznanitev podjetij s samim pristopom ter spodbujanje uporabe benchmarkinga v slovenskih podjetjih. ${ }^{\mathbf{1 5}}$

- V prihodnjih letih lahko pričakujemo povečanje deleža slovenskih podjetij, ki poznajo in uporabljajo uravnoteženi izkaz poslovanja. Leta 2000 je namreč pri Gospodarskem vestniku izšel slovenski prevod knjige "The Balanced Scorecard - Translating Strategy into Action « avtorjev Kaplana in Nortona z naslovom "Uravnoteženi sistem kazalnikov«, ki je v izvirniku izšla leta 1996 pri založbi Harvard Business School Press. Poleg tega je Robert S. Kaplan 18. septembra 2000 predstavil koncept uravnoteženega izkaza poslovanja slovenskim menedžerjem in gospodarstvenikom $v$ okviru Dogodka leta, ki ga je priredil Gospodarski vestnik v Ljubljani.

\subsection{Vpliv uporabe sodobnih menedžerskih orodij na uspešnost poslovanja podjetij ${ }^{16}$}

V okviru celostnega modela sodobnih menedžerskih orodij, ki zagotavlja uspešno poslovanje podjetja, smo ugotovili, da naj bi podjetje poslovalo uspešneje, če uporablja sodobna menedžerska orodja (Tekavčič, Šink, 2002). Uspešnost lahko ugotavljamo s finančnimi in nefinančnimi kazalci. Zaradi lažje primerjave med podjetji smo vzeli finančne kazalce, saj nefinančnih kazalcev nekatera podjetja sploh ne spremljajo, tista, ki pa jih spremljajo, uporabljajo različne nefinančne kazalce, zato vseh podjetij ne moremo primerjati med seboj glede na nefinančne kazalce.

Ugotovili smo, da v povprečju ustvarjajo največji čisti dobiček tista podjetja, ki že uvajajo ali uporabljajo posamezna orodja. $V$ okviru tistih podjetij, ki poznajo posamezna orodja, je povprečna donosnost sredstev (ROA) v povprečju največja pri podjetjih, ki menijo, da bi bilo posamezno orodje smiselno uvesti ali pa celo že

14 Ministrstvo za gospodarstvo $v$ okviru razvojnega programa za pospeševanje konkurenčnosti slovenske industrije za obdobje 2000-2003 podpira več medsebojno povezanih projektov, med katere sodi tudi projekt »Zunanji benchmarking«, ki ga izvaja konzorcij Centra za mednarodno konkurenčnost. Več o omenjenem projektu glej v Mlakar, 2000, str. 4-16.

15 Glede na komentarje tistih, ki so odgovarjali na anketna vprašanja, je v slovenskih podjetjih glavni problem pri vpeljevanju benchmarkinga, da je njegova uporaba predvsem enkratna ali pa omejena na posameznika, ki individualno zbere informacije o konkurentih in izdela t. i. analizo konkurence. Poleg tega je opazen problem dostopa do kakovostnih baz podatkov za potrebe benchmarkinga. Tovrstne baze so pogosto »v rokah« mednarodnih svetovalnih podjetij, zato je dostop do njih največkrat omejen. $16 \mathrm{~V}$ tem poglavju predstavljamo le glavne izsledke raziskave. Za podrobnejši prikaz glej Tekavčič, Peljhan, 2003. 
Tekavčič, Peljhan

\section{Pomen obvladovanja stroškov v javnem sektorju}

načrtujejo njegovo uvajanje, razen pri menedžerskih orodjih ravno ob pravem času, celovito obvladovanje kakovosti in stalne izboljšave poslovanja, pri katerih je povprečna donosnost sredstev največja pri podjetjih, ki že uvajajo ali uporabljajo ta orodja. Za podjetja, ki poznajo posamezna orodja, smo ugotovili, da je delež dobička $v$ prihodkih $v$ povprečju največji pri podjetjih, ki menijo, da bi bilo posamezno orodje smiselno uvesti ali pa celo že načrtujejo njegovo uvajanje, razen pri ciljnih stroških, ravno ob pravem času, celovitem obvladovanju kakovosti, stalnih izboljšavah poslovanja in uravnoteženem izkazu poslovanja, pri katerih je povprečni delež dobička $v$ prihodkih največji pri podjetjih, ki že uvajajo ali uporabljajo omenjena orodja.

Nadalje smo ugotovili, da tista podjetja, ki menijo, da bi bilo posamezno orodje smiselno uvesti ali pa celo že načrtujejo njegovo uvajanje, pogosto dosegajo najvišje kazalce uspešnosti poslovanja, še posebno pri donosnosti sredstev in deležu dobička $v$ prihodkih. Glede na to lahko sklepamo, da so uspešnejša podjetja bolj nagnjena $k$ uvajanju sodobnih menedžerskih orodij. To je tudi smiselno pričakovati, saj je uvajanje sodobnih menedžerskih orodij pogosto povezano z relativno visokim vložkom sredstev (tako denarja kot tudi znanja in časa). Po drugi strani pa se moramo zavedati, da se pozitivni rezultati vpeljave sodobnih menedžerskih orodij lahko pokažejo šele čez nekaj let. Zato bi bilo smiselno ponoviti raziskavo na istem vzorcu podjetij $\vee$ zaporedju npr. vsaj pet let, da bi dobili relevantnejše podatke o vplivu sodobnih menedžerskih orodij na uspešnost poslovanja podjetij.

Za vse skupine podjetij ${ }^{17}$ smo ugotovili, da se razlikujejo po kazalcih uspešnosti poslovanja, kar bomo $v$ nadaljevanju preverili še $z$ uporabo statističnih metod. Pri ugotavljanju odvisnosti uspešnosti poslovanja podjetja od uvajanja in uporabe sodobnih menedžerskih orodij $v$ slovenskih podjetjih smo uporabili postopek preizkušanja hipoteze o enakosti več aritmetičnih sredin za neodvisne vzorce. Za analizo smo uporabili programsko orodje za statistične obdelave SPSS for Windows, različica 10.0, in sicer tako imenovano analizo variance (One-Way ANOVA) za preizkušanje hipoteze o enakosti več aritmetičnih sredin za neodvisne vzorce, torej ničelna hipoteza je $\mathrm{H}_{0}: \mu_{1}=\mu_{2}=\mu_{3}=\mu_{4}$, alternativna hipoteza je tako $\mathrm{H}_{1}$ : vse $\mu_{\mathrm{j}}$ niso enake. ${ }^{\mathbf{1 8}}$ Pri preizkusu $\mathrm{H}_{0}: \mu_{1}=\mu_{2}=\mu_{3}=\mu_{4}$ za neodvisne vzorce predpostavljamo, da se vrednosti opazovane spremenljivke porazdeljujejo

17 Za potrebe analize smo oblikovali štiri skupine podjetij: (1) podjetja, ki ne poznajo pristopa; (2) podjetja, ki poznajo pristop, pa ga ne uvajajo ali uporabljajo oz. se jim to ne zdi smiselno; (3) podjetja, ki menijo, da bi bilo pristop smiselno uvesti ali pa že načrtujejo uvajanje, in (4) podjetja, ki uvajajo ali uporabljajo pristop.

18 Pri teoriji omejitev je ničelna hipoteza $H_{0}: \mu_{1}=\mu_{2}=\mu_{3}$, alternativna hipoteza pa $H_{1}$ : vse $\mu_{j}$ niso enake, ker imamo samo tri skupine podjetij $(1,2$ in 3$)$. 
normalno ${ }^{19}$ in da imajo vse porazdelitve enako varianco. Enakost varianc preizkušamo z Levenovim preizkusom o enakosti varianc (Košmelj, Rovan, 2000).

Na podlagi Levenovega preizkusa o enakosti varianc smo ugotovili, da predpostavka o enakosti varianc ne velja za delež dobička v prihodkih pri vseh proučevanih sodobnih menedžerskih orodjih. Prav tako ta predpostavka ni izpolnjena pri čistem dobičku v okviru teorije omejitev, čistem dobičku in donosnosti kapitala $\checkmark$ okviru koncepta ravno ob pravem času, donosnosti kapitala $v$ okviru celovitega obvladovanja kakovosti ter donosnosti sredstev v okviru stalnih izboljšav poslovanja. $\checkmark$ nadaljevanju bomo komentirali ugotovitve na podlagi analize variance le za tiste kazalce uspešnosti, kjer je predpostavka o enakosti varianc izpolnjena. Pogoj za zavrnitev ničelne hipoteze je, da je stopnja značilnosti pri F-preizkusu manjša ali enaka 0,05.

Pri proučevanju odvisnosti višine čistega dobička od poznavanja in uporabe sodobnih menedžerskih orodij lahko na podlagi vzorčnih podatkov zavrnemo ničelno hipotezo pri zanemarljivi stopnji značilnosti za koncept SAPP, predračunavanje na podlagi aktivnosti, koncept stroškov življenjskega cikla poslovnega učinka, benchmarking, celovito obvladovanje kakovosti in uravnoteženi izkaz poslovanja ter pri stopnji značilnosti 0,003 za koncept ciljnih stroškov, pri stopnji značilnosti 0,001 za koncept stalnih izboljšav poslovanja in pri stopnji značilnosti 0,004 za prenovo poslovnih procesov ter na tej podlagi sprejmemo sklep, da vse aritmetične sredine niso enake. To pomeni, da je povprečna višina čistega dobička odvisna od poznavanja in uporabe zgoraj omenjenih orodij. Za druga orodja tega ne moremo trditi.

Pri proučevanju odvisnosti donosnosti kapitala (ROE) od poznavanja in uporabe sodobnih menedžerskih orodij lahko na podlagi vzorčnih podatkov zavrnemo ničelno hipotezo pri stopnji značilnosti 0,001 za koncept SAPP, pri zanemarljivi stopnji značilnosti za predračunavanje na podlagi aktivnosti, stopnji značilnosti 0,002 za poslovodenje na temelju analize aktivnosti, stopnji značilnosti 0,001 za koncept stroškov življenjskega cikla poslovnega učinka, stopnji značilnosti 0,005 za koncept ciljnih stroškov, stopnji značilnosti 0,008 za teorijo omejitev, stopnji značilnosti 0,007 za benchmarking, stopnji značilnosti 0,003 za koncept stalnih izboljšav poslovanja, stopnji značilnosti 0,003 za prenovo poslovnih procesov in stopnji značilnosti 0,004 za uravnoteženi izkaz poslovanja ter na tej podlagi sprejmemo sklep, da vse aritmetične sredine niso enake. To pomeni, da je povprečna

19 Ker je v našem primeru število proučevanih enot dovolj veliko (gre za dovolj velik vzorec), veljajo sklepi, ki temeljijo na podlagi predpostavke o normalnosti, tudi če se spremenljivke ne porazdeljujejo normalno (Pahor, 2001). Vzorec se šteje za razmeroma majhnega, če ima manj kot 100 enot (Košmelj, Rovan, 2000), zato lahko trdimo, da je naš vzorec, ki to mejo krepko presega, velik. 
Tekavčič, Peljhan

\section{Pomen obvladovanja stroškov v javnem sektorju}

višina donosnosti sredstev odvisna od poznavanja in uporabe zgoraj omenjenih orodij. Za druga orodja tega ne moremo trditi.

Pri proučevanju odvisnosti donosnosti sredstev (ROA) od poznavanja in uporabe sodobnih menedžerskih orodij lahko na podlagi vzorčnih podatkov zavrnemo ničelno hipotezo pri stopnji značilnosti 0,001 za koncept SAPP, stopnji značilnosti 0,004 za predračunavanje na podlagi aktivnosti, stopnji značilnosti 0,028 za poslovodenje na temelju analize aktivnosti, stopnji značilnosti 0,018 za koncept stroškov življenjskega cikla poslovnega učinka, stopnji značilnosti 0,006 za koncept ciljnih stroškov, stopnji značilnosti 0,034 za teorijo omejitev, stopnji značilnosti 0,029 za benchmarking, stopnji značilnosti 0,005 za ravno ob pravem času, zanemarljivi stopnji značilnosti za prenovo poslovnih procesov in stopnji značilnosti 0,004 za uravnoteženi izkaz poslovanja ter na tej podlagi sprejmemo sklep, da vse aritmetične sredine niso enake. To pomeni, da je povprečna višina donosnosti sredstev odvisna od poznavanja in uporabe zgoraj omenjenih orodij. Na podlagi vzorčnih podatkov pa ne moremo zavrniti ničelne hipoteze, da je povprečna višina donosnosti sredstev odvisna od poznavanja in uporabe celovitega obvladovanja kakovosti, saj preizkus tu ni odkril značilnih razlik.

Na podlagi opravljene analize lahko na koncu sklenemo, da se je kot statistično značilna pokazala odvisnost povprečne višine čistega dobička, donosnosti kapitala in sredstev za koncept SAPP, predračunavanje na podlagi aktivnosti, koncept stroškov življenjskega cikla poslovnega učinka, koncept ciljnih stroškov, benchmarking, prenovo poslovnih procesov in uravnoteženi izkaz poslovanja, torej za večino proučevanih orodij. Pri poslovodenju na temelju aktivnosti, teoriji omejitev, konceptu ravno ob pravem času, celovitem obvladovanju kakovosti in konceptu stalnih izboljšav poslovanja pa je bila statistično značilna odvisnost vsaj enega od omenjenih kazalcev uspešnosti poslovanja od poznavanja in uporabe sodobnih menedžerskih orodij.

Uporaba menedžerskih orodij, ki so posredno ali neposredno povezana z obvladovanjem stroškov, je vse pomembnejša tudi za organizacije javnega sektorja, ki se pri iskanju rešitev opirajo na menedžerske prijeme, razvite $v$ podjetjih $v$ proizvodnem sektorju. Organizacije javnega sektorja, ki so se v svetu odločile za tako pot, imajo dobre rezultate (glej npr. Hoque idr., 2004), zato so njihovi dosežki lahko zgled za ravnanje tovrstnih organizacij tudi pri nas. Kljub temu pa pri iskanju pravih rešitev ni mogoče uporabljati le receptov, zato je uvajanje sprememb vedno trdo in naporno delo, ki se ga bodo morale lotiti tudi organizacije javnega sektorja $\checkmark$ Sloveniji. 


\section{Zaključek}

Eno najbolj kritičnih področij $\vee$ dinamičnem poslovnem okolju je zagotovo obvladovanje stroškov, zato bi morala slovenska podjetja in druge organizacije $\vee$ zasebnem in javnem sektorju posebno pozornost posvetiti sodobnim menedžerskim orodjem in njihovemu uvajanju $v$ obstoječe poslovanje. Seveda pa uvajanje teh pristopov samo po sebi ne more zagotoviti večje uspešnosti poslovanja, če podjetja in druge organizacije ne znajo oz. ne bodo znali izkoristiti vseh možnosti, ki jih ta orodja ponujajo. Organizacijam javnega sektorja bodo $\vee$ veliko pomoč glavne ugotovitve prispevka, v katerem smo obravnavali obvladovanje stroškov in njegov pomen za uspešno delovanje vseh podjetij in drugih organizacij, s posebnim poudarkom na organizacijah javnega sektorja, kjer se vse bolj uveljavljajo načela in pristopi, ki so sicer značilni za podjetja, ki delujejo v zasebnem sektorju. Poleg tega smo predstavili uporabo sodobnih menedžerskih orodij $\vee$ slovenskih podjetjih ter na podlagi rezultatov empirične raziskave analizirali vpliv njihove uporabe na uspešnost podjetij.

Nadaljnje smeri raziskovanja se kažejo predvsem $v$ spremljanju uvajanja in uporabe menedžerskih orodij, ki prispevajo k obvladovanju stroškov $v$ slovenskih podjetjih in drugih organizacijah tudi $\vee$ prihodnjih letih ter $\vee$ ocenjevanju pomena prisotnosti uporabe sodobnih menedžerskih orodij na uspešnost poslovanja podjetij, ki bi jo presojali s finančnimi in nefinančnimi kazalci na podlagi panela podatkov. Primerno bi bilo uporabiti tudi t. i. raziskave na terenu, in sicer v najuspešnejših slovenskih podjetjih zasebnega sektorja in organizacijah javnega sektorja. Namen tovrstnih raziskav bi bil predvsem ugotoviti, kakšne načine obvladovanja stroškov uporabljajo ta podjetja ob prilagajanju in uvajanju novih organizacijskih in tehnoloških rešitev $v$ svoje poslovanje ter s tem ugotoviti, uporaba katerih sodobnih menedžerskih orodij je imela $\vee$ praksi slovenskih podjetij najboljše rezultate. Pomanjkanje obsežnejših raziskav s področja obvladovanja stroškov $v$ javnem sektorju se zagotovo kaže kot pomembna priložnost tako za domače kot tudi tuje strokovnjake, katerih raziskovalno delo s področja javnega sektorja bi zapolnilo praznino na tem področju ter pospešilo uvajanje teh orodij tudi v poslovanje organizacij javnega sektorja. 
Tekavčič, Peljhan

\section{Pomen obvladovanja stroškov $v$ javnem sektorju}

Metka Tekavčič je doktorica znanosti s področja poslovnih ved. Zaposlena je na Ekonomski fakulteti v Ljubljani, kjer poleg poučevanja predmetov v okviru Katedre za management in organizacijo že tretje leto deluje tudi kot prodekanica za gospodarske zadeve. Njeno raziskovalno in strokovno delo se osredotoča predvsem na poslovanje podjetij v sodobnih okoliščinah gospodarjenja s poudarkom na obvladovanju stroškov in uporabi sodobnih menedžerskih orodij v podjetjih in drugih organizacijah.

Darja Peljhan je magistrica znanosti s področja poslovodenja in organizacije. Zaposlena je kot asistentka na Ekonomski fakulteti Univerze v Ljubljani, na Katedra za management in organizacijo. $V$ svojem raziskovalnem delu se ukvarja s proučevanjem sodobnih menedžerskih orodij in njihovo uporabo $v$ slovenskih podjetjih.

\section{Literatura in viri}

- Beretta, S., Dossi, A., Grove, H. (2000): »Benchmarking «. Barry J. Brinker (ur.), Guide to Cost Management. New York: John Wiley \& Sons, Inc., str. 242-270.

- Ball, A. (2001): "Discovering its own relevance? Reflections on the 'new' management accounting in the public sector «, Accounting Forum, let. 23, št. 3, str. 283-299.

- Brimson, J. A. (1991): "Activity Accounting: An Activity Based Costing Approach, John Wiley and Sons, Inc., New York.

- Emerging Practices in Cost Management (1999), James B. Edwards (ur.), WG \& L/RIA Group, Boston.

- Emerging Practices in Cost Management: Strategic Cost Management (2000), James B. Edwards (ur.), WG \& L/RIA Group, Boston.

- Feit, D. (2004): "Measuring Performance in the Public Sector «. James B. Edwards (ur.), Emerging Practices in Cost Management. Valhalla: WG \& L/RIA, str. 12-1-I2-7.

- Guide to Cost Management (2000), Barry J. Brinker (ur.), John Wiley \& Sons, New York.

- Han, K. H. (1991): "Management Accounting in the Public Sector «, International Journal of Public Sector Management, let. 4, št. 3, str. 5-17.

- Handbook of Cost Management 2002 edition (2001), John K. Shank (ur.), WG \& L/RIA Group, Boston.

- Hoque, Z., Poage, J. L., Sharma, U., Thor, C. G. (2004): "Performance Management in the Government Sector«. Barry J. Brinker (ur.), Handbook of Cost Management. New York: John Wiley \& Sons, Inc., str. F7B-1 - F7B25.

- Kaplan, R. S. (2000): Uravnoteženi sistem kazalnikov, Gradivo za seminar Dogodek leta 2000, Gospodarski vestnik.

- Kline, J. J. (2003): »Activity-Based Costing and Benchmarking: A Tandem For QualityOriented Governments «, The Journal of Government Financial Management, let. 52, št. 3, str. 50-54.

- Košmelj, B., Rovan, J. (2000): „Statistično sklepanje«, Ekonomska fakulteta, Ljubljana.

- Kruhar, S. (2001): „S pomočjo 20 ključev do izboljšav«, Dnevnik, 18. maj 2001, str. 35. 


\section{Pomen obvladovanja stroškov $v$ javnem sektorju}

- Mlakar, M. (2000): „Benchmarking kot osnova za povečanje konkurenčnosti podjetij«, Gradivo za seminar Benchmarking - kako dohiteti najboljše v panogi in jih prehiteti, CISEF, Ljubljana.

- Podatki in rezultati empirične raziskave "Obvladovanje stroškov v slovenskih podjetjih «, Univerza v Ljubljani, Ekonomska fakulteta, 2000/2001.

- Poulin, E. (2004): „Benchmarking the Hospital Logistics Process «. James B. Edwards (ur.), Emerging Practices in Cost Management. Valhalla: WG \& L/RIA, str. I3-1-I3-4.

- Tekavčič, M. (1996): "Soočanje (preverjanje) notranjih analitičnih ugotovitev z informacijami iz okolja», 2. strokovno posvetovanje o sodobnih vidikih analize poslovanja in organizacije, Zbornik referatov, Zveza ekonomistov Slovenije, str. 112-121.

- Tekavčič, M. (1999): „Vpliv teorije omejitev na poslovno odločanje«, 5. strokovno posvetovanje o sodobnih vidikih analize poslovanja in organizacije, Zbornik referatov, Zveza ekonomistov Slovenije, str. 194-207.

- Tekavčič, M. (1999a): „Teorija omejitev in koncept stroškov po aktivnostih poslovnega procesa: nasprotujoča ali dopolnjujoča se pristopa? «, Slovenska ekonomska revija, let. 50, št. 4, str. 395-408.

- Tekavčič, M. (2001): "Pomen in možnosti obvladovanja stroškov v zdravstvu«, VIII. Dnevi slovenske uprave, Zbornik referatov, Visoka upravna šola, str. 295-314.

- Tekavčič, M., Šink, D. (2002): „The Use of Cost Management Tools for Global Competition: The Case of Slovenian Companies «, International Conference an Enterprise Odyssey: Economics and Business in the New Millenium 2002, Proceedings (CD).

- Tekavčič, M., Šink, D. (2002a): „The Importance of Cost Management Tools and Their Use in Companies Operating in Transition Economies: The Case of Large Slovenian Companies", International Business and Economics Research Journal, let. 1, št. 10, str. 105-117.

- Tekavčič, M., Peljhan, D. (2003): »Insights into Managerial Tools related to Cost Management in Slovenian Companies «, Proceedings of Rijeka Faculty of Economics Journal of Economics and Business, let. 21, št. 1, str. 83-96.

- Turk, I. (2000): „Pojmovnik računovodstva, financ in revizije«, Slovenski inštitut za revizijo, Ljubljana.

- Virant, G. (2003): „Usmerjenost k uporabniku kot načelo delovanja javne uprave«, Uprava, let. 1, št. 2, str. 67-82.

- Zakon o gospodarskih družbah (Uradni list RS, št. 30/93, 29/94, 82/94, 20/98, 84/98, 6/99).

- Zikmund, W. G. (2000): „Business Research Methods«, 6th ed., The Dryden Press, Fort Worth. 
Tekavčič, Peljhan

Pomen obvladovanja stroškov v javnem sektorju

\section{SUMMARY}

\section{The Importance of Cost Management in the Public Sector}

The article is based on a premise that management tools that are directly or indirectly related to cost management used in the private sector can be applied also to the public sector.

Organisations operating in the public sector have to focus increasingly on the cost management that has always been a basic component of any successful business strategy in the private sector. Modern cost management has roots in cost accounting and managerial accounting. Cost management assumes knowledge of both, although the purposes and methods of cost management differ in important ways from those of cost accounting and managerial accounting. The primary purpose of cost accounting has always been to calculate inventory and cost of goods sold for financial statement purposes. In other words, the focus of cost accounting is on external financial reporting. The primary concern of cost management, by contrast, is on internal decision-making.

Although managerial accounting has always been intended to provide decision-support information for the internal use of managers, its emphasis and methods have been attacked unrelentingly since the mid-1980s. The criticisms point out that traditional systems fail to provide relevant and timely information for managerial decision making. Too often, traditional cost systems provide inaccurate and misleading product and customer cost information. They focus too narrowly on historical information. They also emphasize the firm as the unit of analysis, not considering the entire supply chain of which the firm is only a part. In short, they emphasize an historical cost lens, focused from the firm outward, rather than a prospective cost lens, focused upon customers first. Traditional cost systems also contribute to dysfunctional behaviour such as producing excess inventory to absorb overhead or buying substandard raw materials to meet price targets. By contrast, cost management emphasizes better full-stream product and customer information. Cost management helps a company improve its product and processes by reducing waste and other non-value-adding activities. Although modern cost management requires knowledge of cost accounting and managerial accounting, it also assumes intimate familiarity 
with all business processes, and with full stream supply chains. Cost managers cannot measure and manage what they do not understand.

Cost management is a set of techniques and methods for planning, measuring, and reporting to improve a company's products and processes. Its ultimate purpose is to provide information that companies need to provide the value that customer demand. Most people would argue about the basic tools, techniques, and methods that, together, constitute cost management. These tools, techniques, and methods are directly or indirectly related to cost management. They comprise the set of business practices and methods used to support outward looking and strategically oriented companies. During recent years several cost management tools have been introduced in order to help companies improve their decision-making and performance in highly competitive business environment. They include activitybased costing $(A B C)$, activity-based budgeting ( $A B B)$, activity-based management ( $A B M)$, life-cycle costing ( $L C C)$, target costing, theory of constraints (TOC), benchmarking, just-in time (JIT), total quality management (TOM), continuous improvement, business process reengineering (BPR), and balanced scorecard (BSC).

The article focuses on the importance of the cost management tools in the public sector organisations. First, we define cost management as the concept that can be applied to private and public sector organisations. Second, we emphasise the importance of cost management from the public sector point of view. Finally, we provide final results of the empirical research conducted in Slovenian companies. The results presented in the article can be applied to organisations from public and private sector. In the cost management literature, there is a lack of published surveys focused on the public sector organisations. There are some case studies, representing the successful implementations of management tools influencing cost management in the public sector. Surely, these case studies are very informative and useful, especially for organisations that are planning to implement management tools. They can also influence the development of current theoretical models, which are usually more suitable for manufacturing companies. However, the more comprehensive survey researching the state of use of these tools still represents the opportunity and challenge for many researchers in the future. 